fifteen years ago.

The electricity generating boards are not the only organizations to be criticized in the report, however. Criticisms of the Nuclear Installations Inspectorate, the independent body responsible for nuclear safety, made in Parliament last year, is reiterated. The inspectorate needs to put more effort into assessing the PWR, a design new to Britain, says the committee. Two aspects of PWR design, the integrity of the pressure vessel and problems of two phase flow in the water coolant, call for highly specialized inspectors which the inspectorate lacks. The committee recommends that the inspectorate takes on an ultrasonics expert for testing pressure vessels and that the government remedies, by means of legislation if necessary, the inspectorate's difficulty in attracting suitably qualified staff because of uncompetitive salaries.

The UK Atomic Energy Authority (UKAEA) is criticized for past bad advice to government. The committee recommends that its role as adviser to government on nuclear policy be given to the Chief Scientist's office at the Department of Energy. The UKAEA, it says, should confine itself to research on future nuclear options such as the fast breeder reactor and fusion.

One example, in the committee's opinion, was the recommendation not to consider the Canadian CANDU reactor as a possible option. The committee clearly believes that the CANDU reactor offers certain advantages over both the AGR and the PWR but realizes that the government is too committed to its present plan for an about-turn now. Instead, it asks for a study of CANDU before a final commitment to the PWR is made.

Judy Redfearn

\section{European Community}

\section{Research compared}

\section{Brussels}

The European Community seems to have taken fright at the gap between Europe and the United States and Japan in spending on research and development. In his first speech to the European Parliament last week, the president of the European Commission, Gaston Thorn, said that in 1981 the Commission will give priority to research and development that will improve the Community's competitiveness with Japan and the United States. The latest assessment of research spending shows that in Europe as a whole, research and development expenditure accounts for 1.9 per cent of Gross Domestic Product, compared with 2.3 per cent in the United States and 2.0 per cent in Japan. If defence research is excluded, the figures are $1.7 \mathrm{per}$ cent, 1.7 per cent and 2.0 per cent, indicating Japan's present dominance by this yardstick.

What, asked Vincent Ansquer, a French member of the European Parliament, can the Commission do? The answer seems to be that the Commission will hope to increase its own research spending in the next few years from 1.6 per cent to 2.0 per cent of the combined research and development budgets of the member states.

Constitutionally, the Commission is less able to influence national expenditure directly but is working on a series of studies which are to be summarized as guidelines for a common research and development policy due to be presented at the Council of Ministers in June this year.

Community research and development expenditure is assessed each year in a report by the Scientific and Technical Research Committee (CREST). Comparisons between member states have been quite influential in the past; for example, they prompted the French government to make substantial increases in its research budget in both 1979 and 1981 . The latest report, still being finalized, will say that between 1979 and 1980, member governments' expenditure on research grew in real terms by at most 0.4 per cent.

During the whole of the 1970s, it is now clear, growth rates were highest in West Germany, Ireland and the Netherlands, with France, Italy and the United Kingdom below average. In 1980, Italy emerged at the top of the growth table, with an increase of 20 per cent in real terms of its research and development budget.

The CREST report uses information about the objectives of government expenditure in 1970-79 to infer changing priorities. Throughout the Community, government support for "the general promotion of knowledge", still the largest item, is declining. In stark contrast to government declarations, however, European governments seem to have allowed research contributing to industrial productivity and technological development to fall proportionally.

Increased proportions of national budgets have been spent on the exploration of the Earth and the atmosphere, the planning of the human environment and the protection and improvement of human health. The widely acknowledged need to reduce European dependence on imported energy seems not to have received its due over the 1970s, real expenditure increased by a mere 0.4 per cent and actually decreased by 1 per cent immediately after the increase of oil prices in 1973-74. Energy research, nevertheless, has an important role in Italy and Germany, while in Denmark and the Netherlands most government expenditure continues to be "on the general promotion of knowledge',

The influence of defence research expenditure on the pattern of research in individual countries is catalogued in the CREST report. The disparity between the United Kingdom and its partners stands out. Thus British expenditure on defence research grew from 41 per cent of the government's budget in 1970 to 53.3 per cent in 1979. Only France comes anywhere near this proportion, with 35 per cent of the government's budget gaing to defence research in 1979. In the same year, Germany spent 11.7 per cent on defence research and the other six member countries little or nothing. The report does point out, however, that defence research brings industrial spin-off.

The outlines of the committee's picture remain clear enough. Research spending by Community governments is now increasing after the trough in 1978 but still falls short of American expenditure. (The Japanese statistics are incomplete.) In money terms, research and development expenditure in the United States in 1979 was about 1.3 times greater than the corresponding figure for the nine members of the Community. The good news, though, is that in 1980 (according to forecasts of US federal agencies) American government expenditure may have declined while that in Europe remained constant. Jasper Becker

\section{Toxic chemicals}

\section{UK regulations}

The long awaited and potentially contentious draft regulations by which the British government will require the notification of new chemicals were published by the Health and Safety Commission on Wednesday (18 February). The provisional timetable for discussion allows until July for comment, in which case the regulation could become law before the deadline of 18 September laid down by the European Commission. But Brussels, in this as in other matters, is running late and may not be in a position to make its 1979 directive binding on all member states until next year.

The draft regulations are substantially more stringent than the proposals described in the commission's discussion document published in 1977. The principle that they should apply only to new substances remains, but outline notification will now be required for substances manufactured or used in quantites of less than 1 tonne. Chemical manufacturers will now also be required to provide information about biodegradability, thus meeting one of the criticisms of the earlier proposals by environmentalists. One measure of the increased stringency of the draft regulations is that the estimated cost of testing a new chemical is now given as $£ 45,000$.

The proposed regulations for the United Kingdom are more stringent than those required by the European Community in that they apply to chemical intermediates as well as to products supplied to others. This is one of the points on which British chemical manufacturers are likely to concentrate in the coming months, but there will also be complaints that the proposed regulations allow the Health anu Safety Executive to pass on to other European authorities information about 